\begin{tabular}{|c|c|c|}
\hline 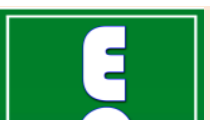 & $\begin{array}{l}\text { International Journal of Current Research in } \\
\text { Biosciences and Plant Biology }\end{array}$ & $=$ \\
\hline & Volume $7 \bullet$ Number 8 (August-2020) • ISSN: 2349-8080 (Online) & \\
\hline $\begin{array}{l}\text { EXCELLENT } \\
\text { PUBLISHERS }\end{array}$ & Journal homepage: $\underline{w w w . i j c r b p . c o m}$ & \\
\hline
\end{tabular}

\title{
A new species of Cycas L. (Cycadaceae) from India
}

\author{
Praveen K. Agrawal ${ }^{*}$, M. Akhtar ${ }^{1}$ and R. C. Srivastava² \\ ${ }^{1}$ Botany Department, Shibli National College, Azamgarh-276 001, Uttar Pradesh, India \\ ${ }^{2}$ Retd. Scientist, Botanical Survey of India, Kolkata-700 064, West Bengal, India \\ *Corresponding author; e-mail: agrawalpk2015@gmail.com
}

\begin{tabular}{|c|}
\hline Article Info \\
\hline $\begin{array}{l}\text { Date of Acceptance: } \\
01 \text { August } 2020\end{array}$ \\
\hline $\begin{array}{l}\text { Date of Publication: } \\
\text { o6 August } 2020\end{array}$ \\
\hline Keywords \\
\hline $\begin{array}{l}\text { Cycas } \\
\text { Karnataka } \\
\text { India } \\
\text { New species } \\
\text { Taxonomy }\end{array}$ \\
\hline
\end{tabular}

\begin{abstract}
A new species of Cycas viz. Cycas bglswamyï Praveen et al., endemic to Bellur locality in Hassan District of the erstwhile Mysore State (now Karnataka State), is reported through this communication. The species seems to be restricted to Bellur area of Hasan district in Karnataka State of India which was under Mysore state of British India.
\end{abstract}

\section{Introduction}

During the studies on living Cycads (Cycadaceae sensu stricto) in India, the authors came across an un-named new species of an endemic species of Cycas (Cycadaceae) discovered and thoroughly worked out by the great Indian Botanist late Prof. B. G. L. Swamy during 1942.

In 1942, Prof. Swamy came across a few pure strands of Cycas in Hassan District of the then Mysore State of India. The area investigated by Prof. Swamy was about 3 sq. miles and the dominat plant type was Cycas without other tree vegetation. Prof. Swamy described this Cycas with details of its macro-morphology, habit, Habitat and worked out its life history in a comprehensive manner. He prepared its habit sketch, branching pattern and other figures related to its life history: He found this Cycas related to Cycas circinallis but differing significantly. He ruled out his plant to be a Cycas circinalis or even Cycas rumphii, but did not give a Scientific (Botanical) name to it.

On the basis of scrutiny of the literature (Brandis, 1906; Lindstrom and Hill, 2007; Pant 2002; Pilger 1926; Sahni, 1990; Singh and Srivastava, 2013; Singh and Raadha, 2008; Swamy, 1948), study of specimens in different herbaria and field studies, the same is being described as a new species as under: 
Cycas bglswamyii D. D. Pant ex P. K. Agrawal, M. Akhtar and R. C. Srivast. sp. nova. Cycas circinalis var. swamyii D. D. Pant (nomen nudum), An Introduction to Gymnsosperms, Cycas and Cycadales, BSIP, Lucknow, India, pp. 52, 55.2002. Affnis C. circinalis (Swamy, 1948).

Type: Iconotype: India: Mysore State, Hasan District, Bellur, 27.12.42, BGLSwamy, 1 (Swamy, BGL in Amer. J. Bot. 35(2), 77-88. 1948). Figs. 1 (A-D).

The comparison of characteristics of three concerned Cycas species are given in Table 1 . Allied to Cycas indica Lindstrom \& Hill (Syn. Cycas swamyi Singh \& Radha) but differs significantly in its habitat, height of trunks, length of leaves, numbers of leaflets, megasporophylls, number of ovules per megasporophyll and length of mature ovules.

Trunks c. $6.5 \mathrm{~m}$ high, with 8-10 whorls of scale leaves alternating with 3-4 whorls of the compound foliage leaves. Compound foliage leaves 90-180cm long (3-6 ft. in length); rachis bearing 60-100 pairs of leaflets. The female cone (apical cluster of megasporphylls) fairly compact; megasporophylls $12.5-17.5 \mathrm{~cm}$ long, short-stalked, tawny-villous, with a more or less triangular serrate tip. Each sporophyll bears five or six ovules; mature ovules $2.5-3.75 \mathrm{~cm}$ long.

Habitat: The area where the plants were found consists of small hillocks with large graniteboulders and hard rocky soil. The plants occur more densely on the ridges and become sparser as the mounds slope down to the level. An accumulation of a large number of viable seeds in the rocky crevices, to which they are probably transported by rodents, seems a possible explanation for the development of young plants in such places. Often the roots of the old plants become exposed by the gradual but continuous washing away of the soil cover (Fig. 1). The roots traverse the soil horizontally to a distance of several meters and may occasionally produce new plants by suckers. Formation of vegetative buds on fairly old trunks is another method of propagation" (Swamy, 1948).

Regeneration/propagation: by suckers or vegetative buds on very old trunks.
Fig. 1 (A)

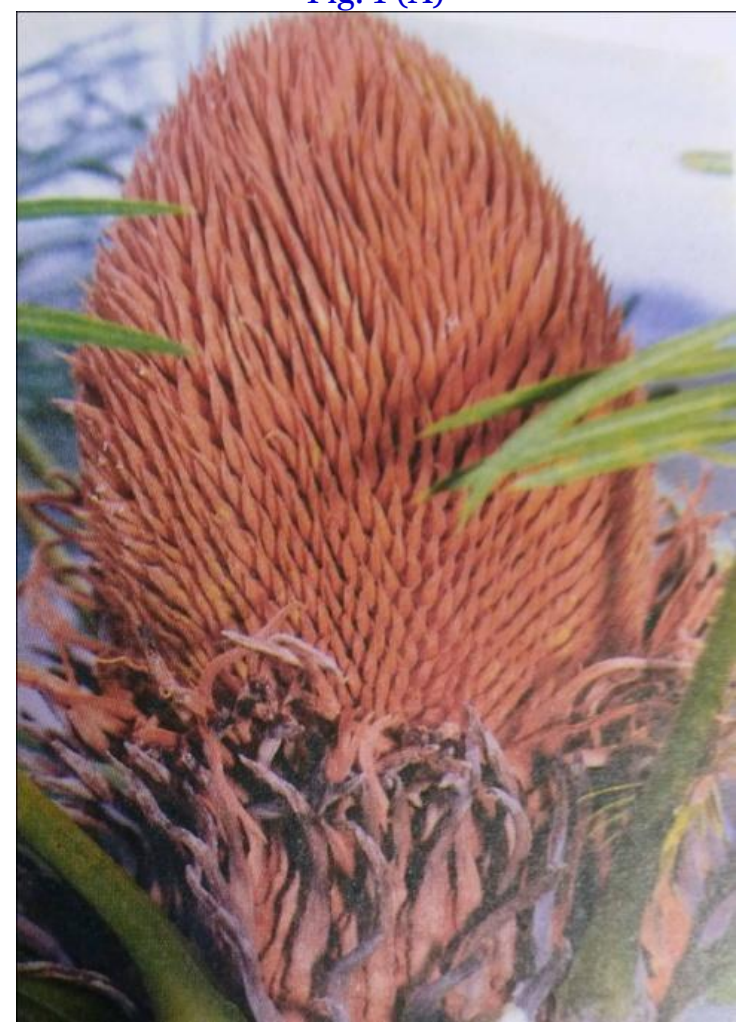

Fig. 1 (B)

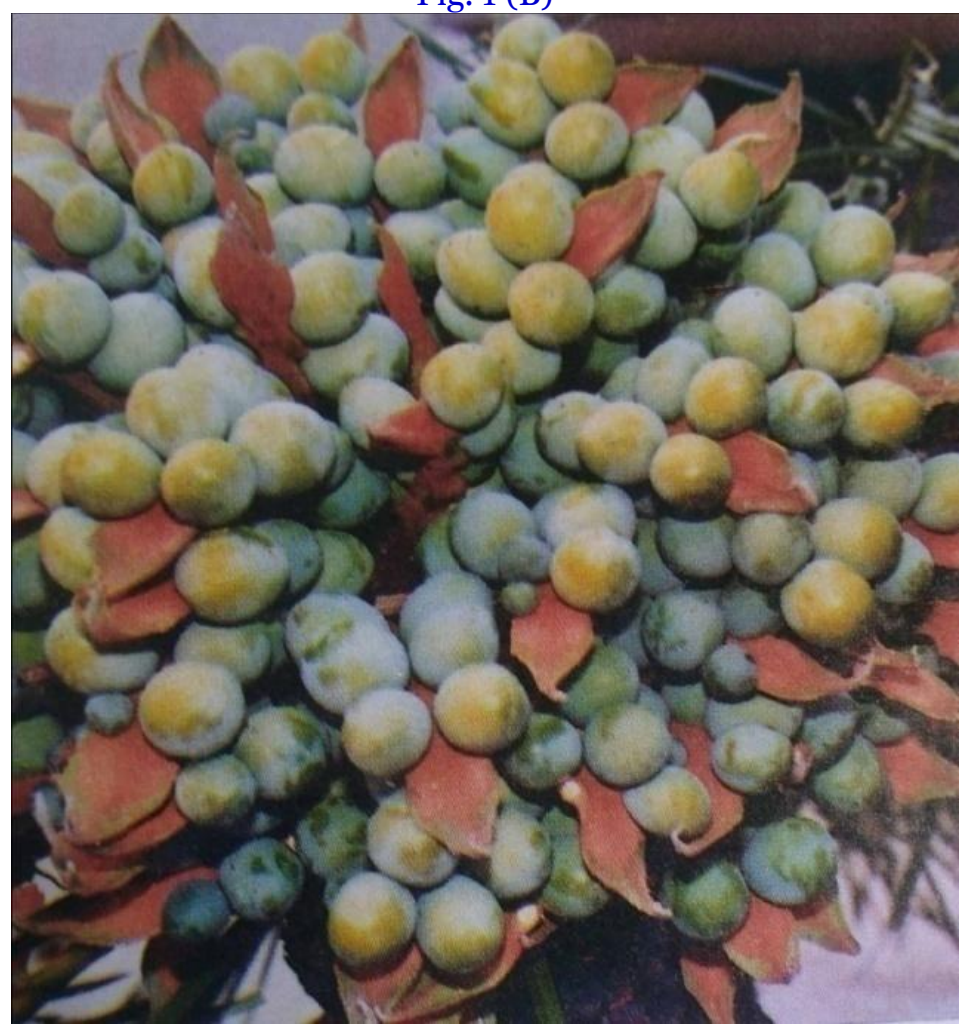


Fig. $1(\mathrm{C})$

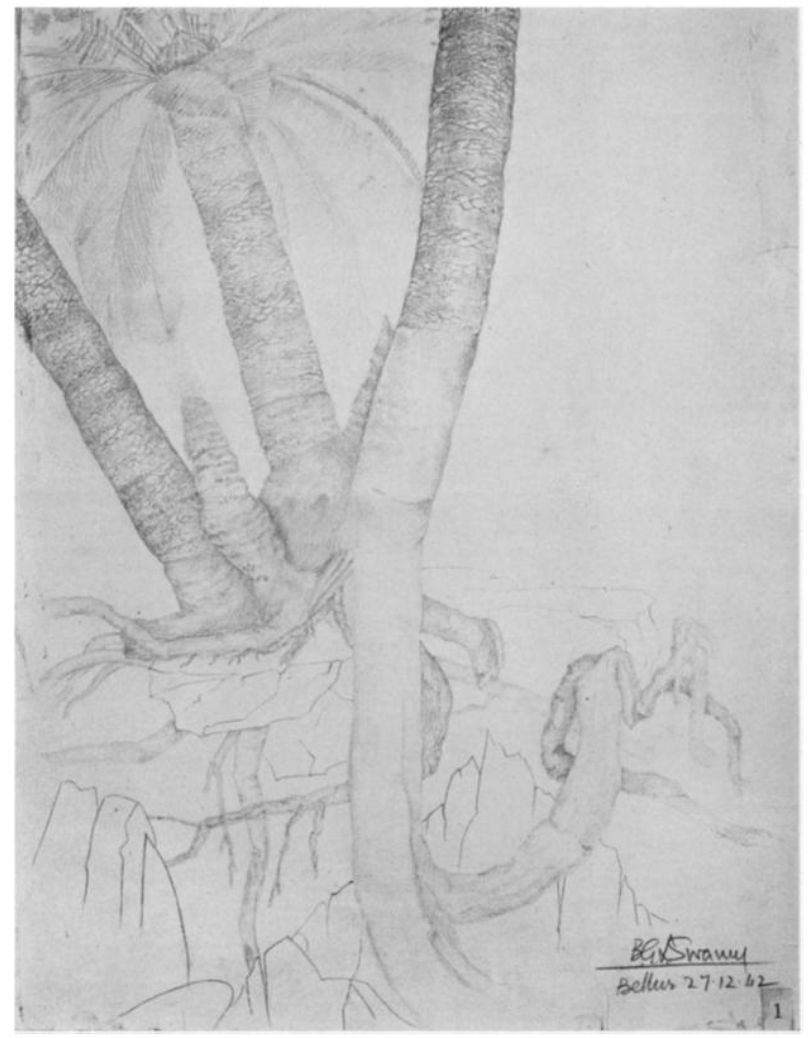

Fig. 1 (D)

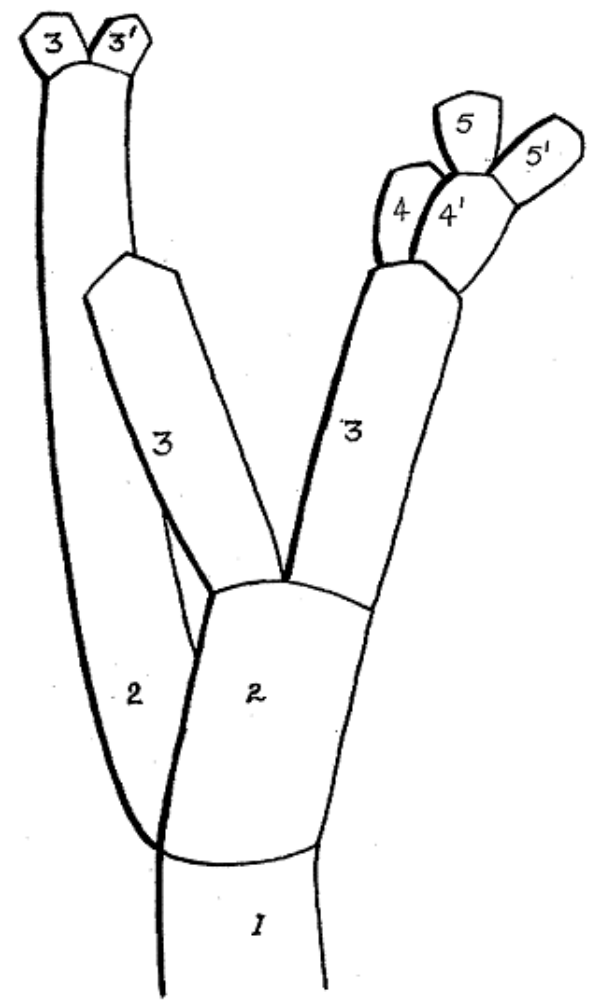

Fig. 1: (A) Cycas bglswamyii - male cone (Photo: D. D. Pant); (B) Cycas bglswamyii: apical cluster of megasporophylls (Photo: D. D. Pant); (C) Habit sketch (Swamy, 1942); (D) Branching pattern (Swamy, 1942).

Table 1. Comparison of different characters of the three concerned species.

\begin{tabular}{llll}
\hline Character(s) & C. bglswamyii & C. indica & C. swamyi \\
\hline Habitat & Small Hillocks & Open rocky habitats & Flat sand-stone \\
Tree height & $6.5 \mathrm{~m}$ & $4 \mathrm{~m}$ & $0.7-8 \mathrm{~m}$ \\
Leaves length & $90-180 \mathrm{~cm}$ & $97-137 \mathrm{~cm}$ & $75-150 \mathrm{~cm}$ \\
Leaflets pairs & $60-100$ & $50-71$ & $55-100$ \\
Megasporophylls & & & \\
Length & $12.5-17.5 \mathrm{~cm}$ long & $18 \mathrm{~cm}$ & $12-25 \mathrm{~cm}$ \\
No. of ovules & $5-6$ & 6 & $4-10$ \\
Ovules length (mature) & $2.5-3.75 \mathrm{~cm}$ & $3.2-3.5 \mathrm{~cm}$ & $2.5-5.2 \mathrm{~cm}$ \\
\hline
\end{tabular}

Notes: "According to Pilger (1926) and Brandis (1906), Cycas circinalis is characterized by: Leaves 5-9 ft., rachis bearing 100-120 pairs of leaflets, female cone fairly loose; carpophylls 6-12 in. (sometimes 18-20 in.), long-stalked, the sterile portion scarcely broadened, long-pointed; upper portion of the carpophyll bearing six-eight ovules. A noteworthy feature of this new Cycas, in the field is the shedding of the foliage leaves at the time of the bearing of the female cones which has never been described in cultivated specimens of either $C$. circinalis or $C$. rumphii. A greater resemblance to $C$. rumphii is indicated in the characters of the leaves and megasporophylls and, most of all, in the type of branching but the character of constant occurrence of larger size and the compressed shape of the ovules (2-3 inches in length) of this species rule out the possibility of this plant to belong to C. rumphii (Swamy, 1948).

\section{Conflict of interest statement}

Authors declare that they have no conflict of interest. 


\section{Acknowledgement}

Authors are grateful to the Principal, Shibli National P.G. College, Azamgarh, for the facilities, Dr Anthony Robert Brach, Inacharge, Harward, Herbarium USA, Dr. Kanchi Gandhi, Harward University (for help in finding the literature) Head, Botany dept and Herbarium, Mysore University for searching his herbarium.

\section{References}

Brandis, D., 1906. Indian Trees, London.

Lindstrom, A. J., Hill, K. D., 2007. The genus Cycas (Cycadaceae) in India. Telopea 11(4), 463-488.
Pant, D. D., 2002. An introduction to Gymnosperms, Cycas and Cycadales, BSIP, Lucknow, India

Pilger, R., 1926. Gymnospermae. In: Engler and Prantl, Die Naturlichen Pflanzenfamilien. 2nd Edn.

Sahni, K. C., 1990. Gymnosperms of india and adjacent countries, Bisenn Singh Mahendra Pal Singh, Dehradun

Singh, N. P., Srivastava, R. C., 2013. Gymnosperms of India: A Check-List, BSI, Kolkata, India.

Singh, R., Radha, P., 2008. A new species of Cycas (Cycadaceae) from Karnataka, India. Bot. J. Linn. Soc. 158, 430-435.

Swamy, B. G. L., 1948. Contributions to the Life History of a Cycas from Mysore (India). Amer. J. Bot. 35(2), 77-88.

\section{How to cite this article:}

Agrawal, P. K., Akhtar, M., Srivastava, R. C., 2020. A new species of Cycas L. (Cycadaceae) from India. Int. J. Curr. Res. Biosci. Plant Biol. 7(8), 22-25. doi: https://doi.org/10.20546/ijcrbp.2020.708.004 